\title{
Playing With Knives: The Socialization of Self-Initiated Learners
}

\author{
David F. Lancy \\ Utah State University
}

\begin{abstract}
Since Margaret Mead's field studies in the South Pacific a century ago, there has been the tacit understanding that as culture varies, so too must the socialization of children to become competent culture users and bearers. More recently, the work of anthropologists has been mined to find broader patterns that may be common to childhood across a range of societies. One improbable commonality has been the tolerance, even encouragement, of toddler behavior that is patently risky, such as playing with or attempting to use a sharp-edged tool. This laissez faire approach to socialization follows from a reliance on children as "self-initiated learners." In this article, ethnographic literature that shows why children are encouraged to learn without prompting or guidance and how that happens is reviewed.
\end{abstract}

Concepts like socialization, parental caretaking styles, and pedagogy are often studied in anthropology within a "cultural models" framework. The framework is built on the assumption that societies incorporate templates or models to guide members (Quinn, 2005) that include customary practices, sanctions for following or not following those practices, and an ethnotheory that organizes these ideas and provides an overarching perspective. "Nso villagers understood themselves as a collective with a strong opinion about what is right and wrong with respect to childrearing goals" (Keller, 2007, p. 105). Ethnotheories have "directive force," meaning that they guide behavior (Harkness, Super, \& Keefer, 1992, p. 170) and identify and correct (or sanction) misbehavior.

To move beyond the study of individual communities and seek out broader patterns characteristic of a range of societies requires a survey of the ethnographic record. Illustrative cases are assembled and analyzed in an inductive process, teasing out commonalities. The analysis presented in this article draws on a very large corpus of such literature, comprising several hundred distinct societies (Lancy, 1996, 2014a). The compiled database is comprehensive with respect to geography and subsistence patterns. The most useful ethnographic accounts for studying cultural models are those where the investigator records not only behavioral patterns, but also the views of participants, typically parents and the children themselves.

Correspondence concerning this article should be addressed to David F. Lancy, Emeritus Professor of Anthropology, Utah State University, 448 E. 100 N., Hyde Park, UT 84318. Electronic mail may be sent to david.lancy@usu.edu.
A fruitful source of clues to the parental ethnotheory is the "culture shock" experienced by the investigator. Accompanied by his spouse during his research on childhood among the Dusun in North Borneo, Williams reports:

We were faced daily with Dusun parents raising their children in ways that violated the basic beliefs by which we were raised. . We consistently checked our. . exclamations of concern or disgust. . .and [resisted] the temptation to take a "dangerous" object, such as a knife, from a toddler. . knowing that in terms of the local culture, children are believed to die from accidents whether they play with knives or not and besides, as one Dusun father put it, "How can you learn to use a knife if you do not use it" (Williams, 1969, p. 3).

This example is typical of observations made by ethnographers that, collectively, suggest a coherent and cohesive cultural model of culture acquisition. The entire community, starting with the children themselves, shares the expectation that children will want to learn. They will want to become competent and helpful. To do this they need free access to artifacts or tools, and opportunities to observe their use by experts. Instruction or supervision, on the other hand, are not considered necessary and may even be seen as counterproductive.

(C) 2015 The Author

Child Development (c) 2015 Society for Research in Child Development, Inc. All rights reserved. 0009-3920/2015/xxxx-xxxx

DOI: $10.1111 /$ cdev. 12498 


\section{Playing With Knives}

[A Pirahã child] was playing with a sharp kitchen knife, about nine inches in length. He was swinging the knife blade around him, often coming close to his eyes, his chest, his arm and other body parts, when he dropped the knife, his mother-talking to someone else-reached backward nonchalantly without interrupting her conversation, picked up the knife and handed it back to the toddler (Everett, 2008, p. 89).

I begin with a dramatic example that vividly illustrates the laissez faire stance characteristic of this parenting style. Further examples show that this is not an isolated case.

[Bonerate] deference to the desires of toddlers and older children in the choice of play objects permitted them frequently to handle sharp knives, large parangs, sharp pieces of scrap iron, and fires (Broch, 1990, p. 61).

"[A Hadza] infant may grab a sharp knife, put it in its mouth, and suck on it without adults showing the least bit of concern until they need the knife again" (Marlowe, 2010, p. 198).

On Vanatinai Island in the South Pacific, "children. . manipulate firebrands and sharp knives without remonstrance. . .one-four year old girl had accidentally amputated parts of several fingers on her right hand" (Lepowsky, 1987).

Similar examples involving a parent's acceptance of a child playing with dangerous objects can be found in virtually every ecological setting around the globe (Lancy, 2014a). Not surprisingly, ethnographers have queried parents regarding this phenomenon. The Hadza say "children will learn on their own what is dangerous" (Marlowe, 2010, p. 198). The Aka (Central African forest foragers) response is also representative:

(Nali) "I don't like it when our children play with machetes, but if the baby decides to play, I leave it. And if the baby cuts themselves and if they see the blood, they themselves will decide not to play with the machete" (Hewlett, 2013, p. $65)$.

Of course some precautions may be taken to prevent injury to clumsy toddlers. The Chewong child may be given an old, blunt knife (Howell, 1988, p. 159). An Aka parent may fashion scaled down but functional tools for a child (Tayanin \& Lindell, 1991). Indeed, a child's "toy" collection consists of small or home-made tools, old and worn tools, and utilitarian items including "fragments of old hunting nets," (Neuwelt-Truntzer, 1981, p. 136) and leftover scraps of skin which will be sewn by a young Inuit girl into a garment for her doll (Jenness, 1922, p. 219). But, from a pragmatic perspective, there are many uncontrollable threats, such as open fires on the ground, and mothers are busy, hence children must learn about hazards on their own. When a Zinacantecan 3-year-old runs, barefoot, through a fire, adults do not react sympathetically. Instead, they comment that the child is flawed in not developing awareness of his surroundings, not paying close attention, and not figuring things out (de León, 2012).

There are at least three themes that emerge from these and similar cases. First, parents may be reluctant to impose their will on young children because of a general bias against hierarchization and assertion of rank. Second, they may believe that children learn best when they are "free to learn" (Gray, 2013). Third, there is the recognition of the child's fascination with and ability to learn from undirected, unrestricted object manipulation.

\section{The Value of Autonomy}

We can discern several core beliefs regarding human nature that are widely shared and which complement each other in terms of a parental theory of socialization. Again, the Aka view is characteristic, "Respect for an individual's autonomy is a core cultural value. . one does not impose his/her will, beliefs, or actions on others" (Hewlett \& Hewlett, 2013, p. 75). This belief has been particularly noted in relatively egalitarian forager bands, "Deciding what another person should do, no matter what his age, is outside the Yequana vocabulary of behaviors" (Gray, 2009, p. 507). But the belief in individual autonomy is actually quite common cross-culturally (Ember, 1991).

A likely greater number of societies do incorporate social rank, and in those, children are at the bottom. My Kpelle adult informants never understood why I should be interested in children, given how little knowledge they have and so little "sense" (Lancy, 1996). "Sense," or intelligence, is identified as a quality that individuals acquire at the outset of middle childhood, ages 5-7. Children 
under 5 are granted great freedom because they are not yet held accountable to practice their subsistence skills in a reliable fashion (Lancy \& Grove, 2011, p. 287).

The belief that children learn through their own initiative, and should be granted sufficient freedom to do so, seems to be extremely widespread. It is assumed that they will want to learn the necessary skills to be helpful (Howard, 1970, p. 37). What varies significantly is the age and degree to which that freedom is withdrawn and children are assigned specific chores. Foraging societies (with noteworthy exceptions, Kramer \& Greaves, 2011) grant children a long period of freedom from responsibility while in farming societies, this freedom is voluntarily, or involuntarily, curtailed (Hewlett, Fouts, Boyette, \& Hewlett, 2011) as early as 5, especially for girls (Lancy, in press). In many foraging societies, the tasks of hunting and gathering are so physically challenging that small children would add to a forager's workload, rather than diminishing it. On the other hand, pastoral and farming communities readily find child-appropriate chores to transition children into the domestic labor force (Hames \& Draper, 2004). A corollary belief is that individuals learn primarily from their own direct experience and that another's perspective may be misleading. Furthermore, the ethnotheory incorporates the idea that children's learning should be self-paced.

Inuit "parents do not presume to teach their children what they can as easily learn on their own" (Guemple, 1979, p. 50).

The relatively few restrictions placed on the young Okinawan child are an important basis for learning. By being able to participate freely, children learn what is going on in their village from day to day (Maretzki \& Maretzki, 1963, p. 514).

$\mathrm{Ju} /$ wasi hunters maintain that hunting is. . something that one just does. . Tracking [cannot] can be taught directly and much depends on the boy's ability to teach himself (Liebenberg, 1990, p. 70).

Inuit children are present [and] exposed to a great deal of talk by older people. Yet. . they were neither expected to participate nor to ask questions of adults. . if they did ask questions [they were ignored] (Crago, 1992, p. 494).

Knives or sharp blades may be the earliest real tool that the child learns to use, in part, because cutting tools are so ubiquitous and important to even the earliest humans.

\section{Learning to Use Tools}

Another element of the self-initiated learner ethnotheory that can be discerned in the knife-handling episodes is an assumption that children will voluntarily seek out tools and tool-like objects for opportunities to explore and use them. "[As] they grow up in a world of tool users, tools become part of the developmental world of young hominins" (Jaffares, 2010, p. 517). Donald (1991, p. 308) and others have noted that each tool in the society's tool kit tells a story, it serves as an "external memory store." When a Bamana child plays with the shorthandled hoe he is been given (Polak, 2011, p. 103), there are only so many ways it can be effectively grasped. If he uses it to pierce the soil-as he observed his siblings doing - the number of possibilities is further reduced. Studies of stone tool production sites dating to the Paleolithic show a characteristic pattern that can be decoded for the evidence of learning. Discarded flakes and crudely made tools show a novice patiently practicing. Nearby may be the remains of an expert's toolmaking debris, suggesting that the one served as a role model for the other (Dugstad, 2010).

Children also demonstrate great resourcefulness and ingenuity in making tools and things to play with. Leacock details an entire catalog of useable items made by boys in a Zambian village, one boy built a play house from sun-dried bricks he had made, a skill he would later use in earnest (Leacock, 1976, p. 470).

There are two sources that ratify the notion that children can learn to use tools properly by freely manipulating them and, later, using them. First, experimental studies in the West, of children as young as 3 months, reveal an enormous range of untutored abilities to learn from objects (Bourgeois, Kwahar, Neal, \& Lockman, 2005). Studies show developmental effects in actions taken on objects. For example, a 1-year-old's motor movements, in using an object as a hammer, show much smoother, consistent, and functional trajectories than a 6month-old infant. "The findings suggest that tool use develops gradually from infants' existing manual behaviors" (Kahrs, Jung, \& Lockman, 2013, p. 810).

However, as Bruner (1976, p. 38) notes, the child's extensive object handling assumes relatively unconstrained access to tools or tool-like objects 
without fear of punishment. As this anecdote shows, we deny these opportunities to our children. A Korean American journalist remarks, "I was surprised in the United States when a nine-year-old asked me to butter his bread because he wasn't 'allowed to use a knife,' even a butter knife" (GrossLoh, 2013, p. 240). This, very recent "overprotectiveness" can be linked to urbanization, the rise in incomes, the decline of family size, and the delay in childbearing. Our few, irreplaceable offspring are redefined as precious treasures rather than future helpers (Zelizer, 1985, p. 171). In the Middle Ages, early childhood was referred to as the "age of concussion" (Heywood, 2001, p. 97). Children were expected to get injured, sick, and with a high probability, die. Today, we believe children should be protected from all forms of risk.

A second and very obvious source of validation of the freedom to "play with knives" in small, faceto-face communities is that even very young children quickly become effective tool users.

Matsigenka "Three-year-olds frequently practice cutting wood and grass with machetes and knives" (Ochs \& Izquierdo, 2009, p. 395).

Maniq (forest foragers) "children play and run with knives all the time. But I never saw a child get hurt when using a knife. On the contrary, at the age of 4 all children can easily skin and gut small animals" (K. Hakami, personal communi3 cation, 2015).

In a photo of a Tapajós River (Amazonia) family gathered to collectively process manioc - each peeling the tubers with a sharp knife-four of the participants are children ranging from three to nine (Medaets, 2013).

In addition to knives, my survey reveals children as young as 3-5 successfully using a hoe to prepare a field for seeding, fishing gear, blowpipe, bow and arrow, mortar and pestle to hull grain, a dugout canoe, and digging stick, among many others. The presumption of a connection between object play leading to competent use was supported in a series of empirical tests carried out among several groups in Botswana (Bock, 2005).

Left unspoken in many of these tool-using stories is an important component of the ethnotheory that is alluded to here:

Four-and-a-half year-old Okinawan children readily peel the outer skin off a length of sugar cane with a sharp sickle. When a mother is asked how the child acquired this skill she [said] "I don't know! He must have watched us and learned himself by trying it out!" (Maretzki \& Maretzki, 1963, p. 511).

That is, it is readily acknowledged that carefully observing proficient tool users is an integral part of the learning process.

\section{Watching and Trying it Out}

Another widely shared assumption built into the cultural model of parenting I am elucidating, is the necessity for children to be able to observe the practice of experts. And this requires no encouragement on the part of parents as children are keen "spectators" (Lancy, 2014a, p. 168) and "imitation machines" (Tomasello, 1999, p. 52). Indeed, recent experimental work has identified a strong tendency for children to "overimitate," to copy the irrelevant actions along with the relevant actions of an adult demonstrator (Whiten, McGuigan, Marshall-Pescini, \& Hopper, 2009). Furthermore, just as experimental studies show that even toddlers are capable of delayed imitation of a model (Meltzoff \& Williamson, 2009, p. 481), so, too, anthropologists describe cases like novice fishers on Samoa who:

might accompany expert fishers and play a supporting role but they never used fishing gear in an expert's presence, nor did an expert offer instruction. Rather the children observed and then, later, borrowed the equipment (nets, spears) to practice on their own, gradually becoming proficient (Odden \& Rochat, 2004, p. 44).

Additional supporting examples are legion because it is patently less costly for an individual to observe and attempt to replicate the proficient behavior of an expert, rather than operate in a social vacuum or "learn individually" (McElreath, 2004). It is also less costly to parents who do not need to waste time on teaching skills the child will acquire on its own (Thornton \& Raihani, 2008, p. 1823). Even with quite complex skills, children are expected to observe and attempt to replicate the actions of those more expert. "Nobody teaches a [Warao] boy how to make a paddle or a canoe because. . Boys learn from watching" (Wilbert, 1976, p. 318). Or, "We don't teach. When [Venda] women make pots some (children and others) come to watch, then go and try" (Krause, 1985, p. 95). 
Hunting is perhaps the single complex skill where opportunities to observe expert practitioners are extremely limited. Tsimanè "men are reluctant to take young children to the forest with them because of the dangers, and because children might make noise, thus spoiling hunting opportunities" (Reyes-Garcia, Broesch, \& TAPS Bolivian Study 4 Team, 2013, p. 208). Boys learn a great deal not only on their own, but also from somewhat older peers (Liebenberg, 1990, p. 69). And boys are free to listen and learn as mature hunters recount their experiences back in the village after the hunt (Tayanin \& Lindell, 1991, p. 14), but the hunters have no pedagogic intent and make no adjustment for the rudimentary knowledge of the aspirant hunters.

Not limited to tool use, the self-initiated learner cultural model encompasses virtually the entire domain of knowledge that a child must acquire to become a competent member of society, including knowledge of their ancestors, sexual intercourse (Fortes, 1970), and of course their mother tongue (Clark, 2005).

The importance of keen attention and observation (Gaskins \& Paradise, 2010) has often been noted by anthropologists. The children of Paraguayan forest foragers:

learn to follow the signs indicating that Ache have walked through an area. These signs. . .consist of bent leaves, twigs, and shrubs... Following these trails is one of the most important forest skills, and most children are successful by about eight. This enables them to navigate between camps without. . adults, and it allows boys to begin small hunting forays without getting lost (Hill \& Hurtado, 1996, p. 223).

It would appear that children who must learn in and from the environment (as opposed to learning from teachers and books) develop characteristically different attention patterns (Rogoff, Correa-Chávez, \& Navichoc-Cotuc, 2005, p. 227). Village children, as well as immigrant children whose mothers have little schooling - invited to learn to make something (e.g. Origami figures) - rely on observing the task as it is carried out by an expert or attempted by other children. "Schooled" individuals pay little attention to the demonstration, waiting for (or soliciting) a teacher's explanation and verbal guidance (Correa-Chavez \& Rogoff, 2005).

It is unsurprising that societies that tolerate children playing with knives should be quite tolerant of play, more generally. And that is clearly the case throughout the ethnographic record with only a very few exceptions (Lancy, 2014a).

\section{Play and Learning}

Unlike the Euro-American cultural model of childhood where parent-child play may be considered "essential," elsewhere adults do not play with children (Lancy, 2007), in large part because it violates the child's independence and takes the adult away from more important activity (Göncü, Mistry, \& Mosier, 2000). While not getting involved directly, parents see the value of play within the peer group and may donate "props" for make-believe play particularly. Biyaka parents "believe. . that if children do not play, they will fail to learn anything" (Neuwelt-Truntzer, 1981, p. 136).

There are a number of profound differences between children's play in the village versus in a modern preschool. First, because of the ubiquity of sibling caretaking (Weisner \& Gallimore, 1977), the play-group is mixed in age. Toddlers are attending to role models just slightly more competent than themselves and likely more patient than busy adults (Maynard \& Tovote, 2010). Indeed, many societies sanction the preferred child-to-child expert/novice pairing. An aspirant Touareg camel herder interacts with and learns from herders who are slightly older, not adults. Adults are too forbidding to ask questions of, or to display ignorance in front of (Spittler, 1998, p. 247).

Second, make-believe play draws on themes from the immediate environment. Play "involves imitation of adult behavior in traditional roles" (Power, 2000, p. 272). The absence of fantasy themed materials (books, videos, toys) means that "Pretending as invention of things beyond the children's real world. . is remarkably rare, if in fact it exists at all" (Gaskins, 2013, p. 230). Consequently, children's play carefully tracks and replicates the activities, customary practices, and attitudes of their elders. For example, I recorded a very lengthy episode of make-believe involving a multiage group that carefully simulated the work and social life that took place daily at the Blacksmith's forge, including facsimiles of the tools typically used (Lancy, 1980). The Blacksmith episode not only shows children's capacity for mimesis-observing and imitating-but also displays invention and interpretation (Gaskins, 2013).

Crittenden (in press) records a type of foraging invented by Hadza youth that does not replicate any specific adult practice. This involves entrapment 
of Weaver bird fledglings, which effectively provides calories for the group, but is conducted entirely in a spirit of play.

Third, make-believe play usually transitions seamlessly into actual work. Play kitchens-with mother providing some ingredients-are used to produce edible food. A group of boys target-shooting with their bows and arrows, soon successfully target edible small animals and birds. Play with a "pet" goat evolves into caring for a small herd. "Watching [Hadza] 3-4-year-olds playing a while, one eventually realizes that children are not just playing but are actually digging small tubers and eating them. . Foraging simply emerges gradually from playing" (Marlowe, 2010, p. 156).

This transition is often facilitated through the availability of scaled tools. Among the Kpelle, every household had 2-4 mortars and pestles. Graduated in size to accommodate varying aged workers, they were used daily (Lancy, 1996). Children's eagerness for this transition from play to useful work is another key element in the cultural model of socialization.

\section{Pitching In}

It is ironic that children who are readily granted the freedom to learn on their own, and who eagerly seize this opportunity, also willingly relinquish some degree of autonomy in order to pitch in and be helpful. As children acquire mastery, they may experience a "feeling of efficacy" (White, 1959, p. 329). Furthermore, children are able to translate new, practical skills into social capital. "When the [Buton] child practices angling on the reef flat, he is catching fish that are consumed by [the] household and this serves, at least in part, as his motivation" (Vermonden, 2009, p. 218).

de Waal (2001) makes the case that the drive to observe and imitate is paired with a drive to "fit in" or the "desire to be like others." This idea was affirmed in a classic study in which children at 18 months of age:

Spontaneously and promptly assisted the adults in a majority of the tasks they performed. Furthermore, the children accompanied their assistance by relevant verbalizations and by evidence that they knew the goals of the tasks, even adding appropriate behaviors not modeled by the adults (Rheingold, 1982, p. 114).

This finding has been replicated and considerably broadened. Eighteen-month-old children assist without being asked and without even making eye contact with the person needing help (Warneken \& Tomasello, 2006). In another study, children overcame obstacles placed in their path in order to assist, and could not be seduced by a play opportunity from trying to assist. Evidently, "young children have an intrinsic motivation to act altruistically" (Warneken \& Tomasello, 2009).

Paradise, Rogoff, and colleagues have studied the practice, in several indigenous villages in Mexico and Guatemala, of inviting children to learn through joint participation in tasks. This has been characterized as the adult "creating room" for the would-be helper (de Haan, 2001, p. 188). Children who seek to assist through collaboration are still expected to have spent time learning through careful observation, imitation, and play. For example, the Mayan weavers studied by Greenfield had first learned to weave on a simple "toy" loom (Greenfield, 2004, p. 37). Learning through collaboration seems to draw on the child's need for mastery and affiliation simultaneously. Most of the characteristics of this particular cultural model of learning are shared with the more general model I have been constructing. They include that the focus is on completion of the task, not on the young assistant. "The emphasis is not on how an individual performs, but rather on what gets accomplished" (Paradise \& de Haan, 2009, p. 196). "Talk supports and is integral to the endeavor at hand rather than becoming the focus of a lesson" (Paradise \& Rogoff, 2009, p. 118). Novices can quickly lose the goodwill of the expert by interrupting, asking questions, or behaving in a way that detracts from the work at hand (Paradise \& Rogoff, 2009, p. 121).

The high degree of task collaboration described in these studies among indigenous villagers in Mesoamerica is certainly observed elsewhere (Polak, 2011), but is by no means universal. Among some forager bands, the long distances travelled by hunters and gatherers through difficult terrain makes children an unacceptable burden. They remain behind in camp (or playing/foraging within a few miles of camp), but still find opportunities to advance their skill at hunting and gathering (Boyette, 2013, p. 88; Crittenden, Conklin-Brittain, Zes, Schoeninger, \& Marlowe, 2013). Among Huaorani foragers in the Amazon, the terrain is not as difficult and distances are shorter, and children as young as three join in foraging expeditions, bringing their own small gathering basket (Rival, 2000, p. 116).

In some societies, children, because of their potential to disrupt the work of their elders, and/or 
because they are considered lacking the responsibility to do the work properly, may actually be rebuffed, or merely tolerated, as volunteer collaborators (Little, 2011, p. 156).

In very recent research in two contrasting societies-Mongol yurt-dwelling pastoralists and lowland Brazilian agro-foragers - the authors uncovered patterns of active discouragement of children's efforts to pitch in. Among Mongols, the bar for participation is raised for children older than 4. An older child who volunteers to pitch in, but who has failed to master the skill in question, is told in sharp terms: "Chi chadahgui! = you can't do $i^{\prime \prime}$ and the task is assigned to someone more competent (Michelet, 2013). The pattern of children volunteering and being rebuffed is codified by communities occupying the Tapajós river region of Brazil in the expression "Tu garante?" Basically, a child wishing to display a formerly unacknowledged skill is challenged to guarantee a competent performance, failing which he or she will be mocked and teased, even by his or her own mother (Medaets, 2013). However, rebuffed children typically redouble their efforts to become fully competent. And a study in the United States showed that children who experienced some ostracism became more diligent at copying a model (Watson-Jones, Legare, Whitehouse, \& Glegg, 2014).

On Samoa, the distance imposed by rank makes it improper for parents, or even older sibling caretakers, to actively collaborate with young learners, but children of about the same age and rank do learn through collaboration (Odden, 2007).

One way to sum up these cases is that socializing self-initiated learners not only implies freedom for the learner, but also freedom for the expert from involvement with the inexpert. There are limits to the freedom granted to child learners. As I have just discussed, societies vary in the degree of tolerance for potentially intrusive would-be helpers. In the next section, I will review situations where the child's freedom to pursue his or her own agenda is suspended or withdrawn.

\section{Limits on Children's Freedom}

An overarching principle that runs through any discussion of indigenous views on socialization is that actions taken by adults are rarely designed primarily to benefit the child learner. As we have seen, in egalitarian societies, no one's autonomy should be imposed upon, even for their own good. Elsewhere, autonomy is granted or withheld as much for the convenience of the parent as it is to facilitate the child's learning. Keller has compared parental ethnotheories of middle class Germans and Cameroonian Nso villagers. In the Nso case, children's early self-sufficiency is valued; children are expected to control their emotions and attend to others. Germans value children's individuality and self-expression, and are less demanding in terms of compliance (Keller, 2007; Keller \& Otto, 2009). So, while the Nso grant their young children considerable latitude, they are to apply their freedom to the challenge of unburdening their caretakers and learning useful skills.

Restrictions on children are best viewed through a developmental lens. Infants are granted little or no free exploration. Beginning at birth, the ethnographic record is rich with descriptions (Lancy, 2014b) of infants being secluded, encased in various kinds of external or marsupial-like containers attached to the mother's body, and constrained within swaddling, cradleboards, baskets, and childminders. This treatment is in accord with parental ethnotheories that stress the need for the infant to remain at all times in a quiescent state - excitement is harmful; the spastic movements infants make could lead to deformity; free movement, including crawling, is animal-like and must be suppressed; and the infant is incapable of learning or making any sense of the world (Lancy, 2014a). For example:

A [!Kung] child who is nursing has no awareness of things. Milk, that's all she knows. Even when she learns to sit, she still doesn't think about anything because her intelligence hasn't come to her yet (Shostak, 1981, p. 113).

Also, from a pragmatic standpoint, mothers are busy and have little inclination toward extensive interaction with their infants (Takada, 2012, p. 69). A historian notes, "A swaddled baby, like a little turtle in its shell, could be looked after by another, only slightly older child. . . since the practice of swaddling made. . childcare virtually idiot proof" (Calvert, 1992, pp. 23-24). As little autonomy as the infant has, they do put it to good use, "Zinacanteco infants. . quiet and alert, attentively observe their surroundings, laying the foundation for later observational learning" (Greenfield, Brazelton, \& Childs, 1989, p. 207).

In the same spirit of strategizing to reduce the burden of child care, a number of societies accelerate the child's progress toward sitting and walking. In effect, self-initiated learning is not adequate. ! Kung foragers accelerate independent locomotion 
because "in the traditional mobile subsistence pattern. . .children who cannot walk constitute major burdens" (Konner, 1976, p. 290). Various practices are followed, including dandling the infant on someone's knees (shown experimentally to speed up the onset of walking; Zelazo, Zelazo, \& Kolb, 1972) and aiding its first steps.

Another case of acceleration occurs in societies that consider sharing to be one of the traits that distinguish fully human individuals. For example, Papel infants are given something desirable, such as a snack, then immediately told to pass it on to another, particularly a sibling (Einarsdóttir, 2004, p. 94). However, like standing and walking, children appear to spontaneously exhibit prosocial behavior, including sharing, from the age of 3 or earlier (House, Henrich, Brosnan, \& Silk, 2012).

Earlier, I mentioned children volunteering to help out. Parents not only welcome their help, but as they become proficient, they also begin to assign them chores. This is particularly true in agrarian communities with high fertility. For example, the "Giriama attach importance to providing children with duties that teach responsibility and mutuality" (Wenger, 1989, p. 93). A 3-year-old might be sent on an errand, a 5-year-old might be assigned to gather firewood or fetch water from a stream. Anthropologists often observe youngsters no older than 5 carrying and looking after an infant (Lancy, 2014a). Gradually, more demanding and complex tasks are assigned, consonant with the child's maturity and motivation (Lancy \& Grove, 2011). As children are so cooperative, and, at least initially, welcome the responsibility of caring for a younger sibling, for example, the loss of freedom may not be immediately apparent. However, there are certainly cases of children diverted from play or other preferred activity to do chores. Tsimanè boys, who'd rather be hunting, may be assigned sib-care duty during the rice harvest (Stieglitz, Gurven, Kaplan, \& Hooper, 2013, p. 9). Among the Inuit, "a girl was expected to interrupt her play activities to assist her mother with such tasks as cutting fresh ice. . .and gathering moss" (Condon, 1987, p. 55). A significant proportion of the numerous cases of punishment of a child in the ethnographic record arise in relation to chores. An Amhara adult may "encourage a child to do its chores by throwing clods of dirt or manure at him" (Levine, 1965, p. 266)."

Across a broad range of societies, girls become closely attached to their mothers, especially if she's got an infant to nurse. A daughter serves, in effect, as an assistant and understudy (Paradise \& Rogoff,
2009, p. 113). Much of the joint activity with the mother advances her knowledge of how to manage in the domestic sphere, care for gardens, and so on. But, while boys of the age of three and beyond gain greater freedom from home and expanded opportunities to play with peers, girls' territory and play opportunities diminish (Edwards, 2005). In many societies, however, even boys find that, by age seven or middle childhood, their assigned chores take precedence over play with peers. Overall, there is wide variability in the amount of time that a child at a particular age might spend in "work," and this is affected by numerous variables, including the nature of subsistence, the season, and family size (Kramer \& Greaves, 2011). Variability within a single community arises because a child may be suddenly conscripted to fill a slot in the domestic workforce that has been vacated due to another family member's illness, death, temporary migration, school attendance, and so on (Lancy, 2014a, p. 280). As a broad generalization then, most children who have reached the stage of middle childhood are expected to forego some of their freedom and "pitch in," or are called upon to help, depending on the extent of family need.

\section{Summary and Implications}

I have argued that permitting very young children to "play with knives" derives from a widely distributed cultural model of socialization. This model includes an ethnotheory that guides and explains the behavior of parents vis-à-vis their developing, skill-acquiring offspring. Children are permitted to play with knives because on ethical (it is wrong to impose one's will on another) and practical grounds, it is fruitless to interfere with a child's will; children learn best through their individual, self-guided exploration and use of objects like knives; self-injury should be a learning opportunity; and a self-starting learner relieves the parent of playing the role of teacher.

Evidence was presented from infant-child research in the West as well as ethnography, which strongly reinforces several of these "folk" ideas. Children do learn a great deal about objects and their proper use through free exploration. However, another key element of the model is that observation of skilled practitioners is also vital. To that end, children are not only free to play with knives, but they are also free to closely observe knife (and other tool) users-during butchering, for example. Indeed, there are very few places, objects, or scenes 
that are blocked to the very young, so children learn not only practical skills, but also learn about their ancestors, domestic conflict, community history, and folklore, among others. Furthermore, work by cognitive anthropologists suggests that where the influence of schooling is still weak, young children continue to develop and use the very keen observation abilities that are already evident in infants.

Children learn skills in a social context (Lave \& Wenger, 1991) and, almost invariably, that means in the company of peers. Play, including especially, make-believe play, incorporating both the tools and the processes in which they are used, provides a parentally approved opportunity to develop competence. This is especially so since at least some of one's playmates will be older, more sophisticated practitioners of whatever work activity or social process is being reconstructed in play.

The self-initiated learner is mastering useful skills-from sweeping the house floor with a bundle of twigs, to catching enough fish to feed the family. Not only do these prosocial acts emanate from the evolved psychology of the child, but they are also congruent with the expectations of the indigenous cultural model of childhood. In some societies, this mutuality encompasses collaborative adult-child work activity where the child's contribution matches their level of skill, and both ratchet upward in sync. However, the child's very usefulness may lead to a loss of autonomy where the parent requests or demands that the child carry out a chore in lieu of play or further skill development in another activity. This is particularly true for girls, and for both sexes in societies that depend on subsistence farming.

Teaching is largely absent from the cultural model that emerges from the ethnographic record. It may be specifically proscribed as diverting the child from the "normal" process of self-guided learning through direct (rather than mediated by a teacher) experience. Even in learning that is collaborative, the expert does not behave didactically or use language designed to instruct. There are clusters of societies whose cultural model of socialization identifies areas where the child's self-paced learning is seen as operating too slowly, and others instruct the child in order to accelerate acquisition of the relevant behaviors. However, in other areas of knowledge and skill, these societies honor the self-initiated learner ideal.

The universal, or near-universal, cultural model of socialization that I have outlined in this article is completely compatible with current perspectives on the role of child learners of culture in human evolution. The model essentially matches the theory of social learning as offered by Bandura (1977) and considerably expanded since (Whiten et al., 2009). It focuses on the child's manifold capacities for learning about the physical and social environment, which are mediated or guided by the appearance, speech, behavior, and cooperation of others, usually more expert. Culture is sustained, augmented, and changed through the attempts of new members to take advantage of this ready-made survival tool kit. Children as self-initiated learners are perfectly adapted to the "cultural niche."

Our uniquely developed ability to learn from others is absolutely crucial for human ecological success. This capacity enables humans to gradually accumulate information across generations and develop well-adapted tools, beliefs, and practices that no individual could invent on their own. We have entered the "cultural niche," and our exploitation of this niche has had a profound impact on the trajectory of human evolution (Boyd, Richerson, \& Henrich, 2011, p. 10919).

But as we have seen, children's mimesis is imperfect. The Pirahã child waving a knife around is not imitating anyone-at the moment. Children routinely deviate from observed patterns. They create or invent tools when no real ones are available, and their make-believe "interprets" reality, often in ways that suggest parody. Children are not constrained to learn from only a single individual. On the contrary, they draw on peers, older siblings, extended kin-especially grandparentsas well as their own parents as role models. No two models will be identical, so the child's products or processes, as the combination of multiple models, are bound to be original. Self-initiated learners can be seen as a source for both the endurance of culture and of change in cultural patterns and practices.

\section{References}

Bandura, A. (1977). Social learning theory. Englewood Cliffs, NJ: Prentice Hall.

Bock, J. (2005). Farming, foraging, and children's play in the Okavango Delta, Botswana. In A. Pellegrini \& P. K. Smith (Eds.), The nature of play: Great apes and humans (pp. 254-281). New York, NY: Guilford.

Bourgeois, K., Kwahar, A. W., Neal, S. A., \& Lockman, J. J. (2005). Infant manual exploration of objects, surfaces and their interrelations. Infancy, 8, 233-252. 
Boyd, R., Richerson, P. J., \& Henrich, J. (2011). The cultural niche: Why social learning is essential for human adaptation. Proceedings of the National Academy of Sciences of the United States of America, 108, 1091810925.

Boyette, A. H. (2013). Social learning during middle childhood among Aka foragers and Ngandu farmers of the Central African Republic. Unpublished Ph.D. dissertation, Washington State University, Pullman, WA.

Broch, H. B. (1990). Growing up agreeably: Bonerate childhood observed. Honolulu, HI: University of Hawai'i Press.

Bruner, J. S. (1976). Nature and uses of immaturity. In J. S. Bruner, A. Jolly, \& K. Sylva (Eds.), Play-Its role in development and evolution (pp. 28-64). New York, NY: Basic Books.

Calvert, K. (1992). Children in the house: The material culture of early childhood, 1600-1900. Boston, MA: Northeastern University Press.

Carrier, A. H. (1985). Infant care and family relations on Ponam Island, Manus Province, Papua New Guinea. In L. B. Marshall (Ed.), Infant care and feeding in the South Pacific (pp. 189-205). New York, NY: Gordon and

6 Breach.

Clark, E. V. (2005). First language acquisition. Cambridge, MA: Cambridge University Press.

Condon, R. G. (1987). Inuit youth: Growth and change in the Canadian Arctic. New Brunswick, NJ: Rutgers University Press.

Correa-Chavez, M., \& Rogoff, B. (2005). Cultural research has transformed our ideas of cognitive development. International Society for the Study of Behavioral Development Newsletter, 47, 7-10.

Crago, M. B. (1992). Communicative interaction and second language acquisition: An Inuit example. TESOL Quarterly, 26, 487-505.

Crittenden, A. N. (in press). Children's foraging and play among the Hadza. In C. L. Mehan \& A. N. Crittenden (Eds.), Origins and implications of the evolution of child-

7 hood (pp. ???-???). Santa Fe, NM: SAR Press.

Crittenden, A. N., Conklin-Brittain, N. L., Zes, D. A., Schoeninger, M. J., \& Marlowe, F. W. (2013). Juvenile foraging among the Hadza: Implications for human life history. Evolution and Human Behavior, 34, 299-304.

Csibra, G., \& Gergely, G. (2011). Natural pedagogy as evolutionary adaptation. Philosophical Transactions of the

8 Royal Society B: Biological Sciences, 366, 1149-1157.

de Haan, M. (2001). Intersubjectivity in models of learning and teaching: Reflection from a study of teaching and learning in a Mexican Mazahua Community. In S. Chaiklin (Ed.), The theory and practice of cultural-historical psychology (pp. 174-199). Aarhus, Denmark: Aarhus University Press.

de León, L. (2012). Socializing attention: Directive sequences, participation, and affect in a Mayan family at work. Unpublished MS, CIESAS, Mexico.

de Waal, F. (2001). The ape and the sushi master. New York, NY: Basic Books.
Donald, M. (1991). Origins of the modern mind: Three stages in the evolution of culture and cognition. Cambridge, MA: Harvard University Press.

Dugstad, S. A. (2010). Early child caught knapping: A novice early mesolithic flintknapper in south-west Norway. In Proceedings from the 2nd International Conference of the Society for the Study of Childhood in the Past (pp. 65-74). Stavanger, Norway: University of Stavanger.

Edwards, C. P. (2005). Children's play in cross-cultural perspective: A new look at the Six Culture Study. In F. F. McMahon, D. E. Lytle, \& B. Sutton Smith (Eds.), Play: An interdisciplinary synthesis (pp. 81-96). Lanham, MD: University Press of America.

Einarsdóttir, J. (2004). Tired of weeping: Mother love, child death, and poverty in Guinea-Bissau. Madison, WI: University of Wisconsin Press.

Ember, C. R. (1991). Commentary on Foragers' pursuit of individual autonomy. Current Anthropology, 32, 561562.

Everett, D. L. (2008). Don't sleep there are snakes: Life and language in the Amazonian Jungle. New York, NY: Pantheon Books.

Fortes, M. (1970). Social and psychological aspects of education in Taleland. In J. Middleton (Ed.), From child to adult: Studies in the anthropology of education (pp. 14-74). Garden City, NJ: The Natural History Press.

Gaskins, S. (2013). Pretend play as culturally constructed activity. In M. Taylor (Ed.), The Oxford handbook of the development of imagination (pp. 224-247). New York, NY: Oxford University Press.

Gaskins, S., \& Paradise, R. (2010). Learning through observation in daily life. In D. F. Lancy, S. Gaskins, \& J. Bock (Eds.), The anthropology of learning in childhood (pp. 85-117). Lanham, MD: AltaMira Press.

Geertz, H. (1961). The Javanese family: A study of kinship and socialization. New York, NY: Free Press.

Göncü, A., Mistry, J., \& Mosier, C. (2000). Cultural variations in the play of toddlers. International Journal of Behavioral Development, 24, 321-329.

Gosso, Y., Otta, E., De Lima, M., Morais, S., Ribeiro, E., \& Leite, F. J. (2005). Play in hunter-gatherer society. In A. D. Pellegrini \& P. K. Smith (Eds.), The nature of play: Great apes and humans (pp. 213-253). New York, NY: Guilford.

Gray, P. O. (2009). Play as a foundation for hunter-gatherer social existence. American Journal of Play, 1, 476522.

Gray, P. O. (2013). Freedom to learn. New York, NY: Basic Books.

Greenfield, P. M. (2004). Weaving generations together: Evolving creativity in the Maya of Chiapas. Santa Fe, NM: SAR Press.

Greenfield, P. M., Brazelton, T. B., \& Childs, C. P. (1989). From birth to maturity in Zinacantan: Ontogenesis in cultural context. In V. Bricker \& G. Gosen (Eds.), Ethnographic encounters in Southern Mesoamerica (pp. 177-216). Albany, NY: State University of New York Press. 
Gross-Loh, C. (2013). Parenting without borders. New York, NY: Avery.

Guemple, D. L. (1979). Inuit socialization: A study of children as social actors in an Eskimo community. In I. Karigoudar (Ed.), Childhood and adolescence in Canada (pp. 39-71). Toronto, Canada: McGraw-Hill Ryerson.

Hames, R., \& Draper, P. (2004). Women's work, childcare, and helpers at-the-nest in a hunter-gatherer society. Human Nature, 15, 319-334.

Harkness, S., Super, C., \& Keefer, C. H. (1992). Learning to be an American parent: How cultural models gain directive force. In R. D'Andrade \& C. Strauss (Eds.), Human motives and cultural models (pp. 163-178). Cambridge, UK: Cambridge University Press.

Hewlett, B. L. (2013). Listen, here is a story. New York, NY: Oxford University Press.

Hewlett, B. S., Fouts, H. N., Boyette, A. H., \& Hewlett, B. L. (2011). Social learning among Congo Basin huntergatherers. Philosophical Transactions of the Royal Society B: Biological Sciences, 366, 1168-1178.

Hewlett, B. L., \& Hewlett, B. S. (2013). Hunter-gatherer adolescence. In B. L. Hewlett (Ed.), Adolescent identity (pp. 73-101). New York, NY: Routledge.

Heywood, C. (2001). A history of childhood: Children and childhood in the West from medieval to modern times. Cambridge, MA: Polity Press.

Hill, K., \& Hurtado, A. M. (1996). Ache life history: The ecology and demography of a foraging people. New York, NY: Aldine de Gruyter.

House, B. R., Henrich, J., Brosnan, S. F., \& Silk, J. B. (2012). The ontogeny of human prosociality: Behavioral experiments with children aged 3 to 8. Evolution and Human Behavior, 33, 291-308.

Howard, A. (1970). Learning to be Rotuman. New York, NY: Teachers College Press.

Howell, S. (1988). From child to human: Chewong concepts of self. In G. Jahoda \& I. M. Lewis (Eds.), Acquiring culture: Cross cultural studies in child development (pp. 147-168). London, UK: Croom Helm.

Jaffares, B. (2010). The co-evolution of tools and minds: cognition and material culture in the hominin lineage. Phenomenology and the Cognitive Science, 9, 503-520.

Jenness, D. (1922). The life of the Copper Eskimos. Report of the Canadian Arctic Expedition, 1913-18, 12(A), Ottawa, Canada.

Kahrs, B. A., Jung, W. P., \& Lockman, J. J. (2013). Motor origins of tool use. Child Development, 84, 810-816.

Keller, H. (2007). Cultures of infancy. Mahwah, NJ: Erlbaum.

Keller, H., \& Otto, H. (2009). The cultural socialization of emotion regulation during infancy. Journal of Cross-Cultural Psychology, 40, 996-1011.

Konner, M. J. (1976). Maternal care, infant behavior and development among the Kung. In R. B. Lee \& I. DeVore (Eds.), Studies of the !Kung San and their neighbors (pp. 218-245). Cambridge, MA: Harvard University Press.
Kramer, K. L., \& Greaves, R. D. (2011). Juvenile subsistence effort, activity levels, and growth patterns. Human Nature, 22, 303-326.

Krause, R. A. (1985). The clay sleeps: An ethnoarchaeological study of three African potters. Birmingham, AL: The University of Alabama Press.

Lancy, D. F. (1980). Becoming a blacksmith in Gbarngasuakwelle. Anthropology and Education Quarterly, 11, 266-274.

Lancy, D. F. (1996). Playing on the mother ground: Cultural routines for children's development. New York, NY: Guilford.

Lancy, D. F. (2007). Accounting for variability in motherchild play. American Anthropologist, 109, 273-284.

Lancy, D. F. (2012a). The chore curriculum. In G. Spittler \& M. Bourdillion (Eds.), African children at work: Working and learning in growing up (pp. 23-57). Berlin: Lit Verlag.

Lancy, D. F. (2012b). First you must master pain: The nature and purpose of apprenticeship. Society for the Anthropology of Work Review, 33, 113-126.

Lancy, D. F. (2014a). The anthropology of childhood: Cherubs, chattel, changelings (2nd ed.). Cambridge, MA: Cambridge University Press.

Lancy, D. F. (2014b). Babies aren't persons: A survey of delayed personhood. In H. Otto \& H. Keller (Eds.), Different faces of attachment: Cultural variations of a universal human need (pp. 66-112). Cambridge, MA: Cambridge University Press.

Lancy, D.F. (in press). Children as a reserve labor force. Current Anthropology.

Lancy, D. F., \& Grove, M. A. (2011). Getting noticed: Middle childhood in cross-cultural perspective. Human Nature, 22, 281-302.

Lave, J., \& Wenger, E. (1991). Situated learning: Legitimate peripheral participation. Cambridge, MA: Cambridge University Press.

Leacock, E. (1976). At play in African villages. In J. S. Bruner, A. Jolly, \& K. Sylva (Eds.), Play-Its role in development and evolution (pp. 466-473). New York, NY: Basic Books.

Lepowsky, M. A. (1987). Food taboos and child survival: A case study from the Coral Sea. In N. Scheper-Hughes (Ed.), Child survival: Anthropological perspectives on the treatment and maltreatment of children (pp. 71-92). Dordrecht, The Netherlands: D. Reidel.

Levine, D. N. (1965). Wax and gold: Tradition and innovation in Ethiopian culture. Chicago, IL: University of Chicago Press.

Liebenberg, L. (1990). The art of tracking. Cape Town, South Africa: Creda Press.

Little, C. A. J. L. (2011). How Asabano children learn; or, formal schooling amongst informal learners. Oceania, 81, 146-166.

Maretzki, T. W., \& Maretzki, H. (1963). Taira: an Okinawan village. In B. B. Whiting (Ed.), Six cultures: Studies of child rearing (pp. 363-539). New York, NY: Wiley.

Marlowe, F. W. (2010). The Hadza: Hunter-gatherers of Tanzania. Berkeley, CA: University of California Press. 
Maynard, A. E., \& Tovote, K. E. (2010). Learning from other children. In D. F. Lancy, S. Gaskins, \& J. Bock (Eds.), The anthropology of learning in childhood (pp. 181205). Lanham, MD: AltaMira Press.

McElreath, R. (2004). Social learning and the maintenance of cultural variation: An evolutionary model and data from East Africa. American Anthropologist, 106, 308-321.

Medaets, C. V. (2013). "Tu garante?" Local ideas on childhood, cultural transmission and learning practices along the Tapajós River. Paper presented at the joint SPA/AYCIG meeting, San Diego, CA, February.

Meltzoff, A. N., \& Williamson, R. A. (2009). Imitation. In R. A. Shweder (Ed.), The child: An encyclopedic companion (pp. 480-481). Chicago, IL: The University of Chicago Press.

Michelet, A. (2013). What is there to learn from not being taught? Learning pastoral and domestic skills in southern Mongolia. Paper presented at the joint SPA/AYCIG

15 meeting, San Diego, CA, February.

Neuwelt-Truntzer, S. (1981). Ecological influences on the physical, behavioral, and cognitive development of Pygmy children. Unpublished Ph.D. dissertation, The University of Chicago, Chicago, IL.

Nicolaisen, I. (1988). Concepts and learning among the Punan Bah of Sarawak. In G. Jahoda \& I. Lewis (Eds.), Acquiring culture: Cross-cultural studies in child develop-

16 ment (pp. 193-221). London, England: Croom Helm.

Ochs, E., \& Izquierdo, C. (2009). Responsibility in childhood: Three developmental trajectories. Ethos, 37, 391413.

Odden, H. L. (2007). The acquisition of cultural knowledge of hierarchy by Samoan children. Unpublished Ph.D. dissertation, Emory University, Atlanta, GA.

Odden, H. L., \& Rochat, P. (2004). Observational learning and enculturation. Educational and Child Psychology, 21, 39-50.

Paradise, R., \& de Haan, M. (2009). Responsibility and reciprocity: Social organization of Mazahua learning practices. Anthropology and Education Quarterly, 40, 187204.

Paradise, R., \& Rogoff, B. (2009). Side by side: Learning by observing and pitching in. Ethos, 37, 102-138.

Polak, B. (2011). Die Könige der Feldarbeit. Unpublished Ph.D. dissertation, Kulturwissenschaftlichen Fakultät

der Universität Bayreuth, Bayreuth, Germany.

Power, T. G. (2000). Play and exploration in children and animals. Mahwah, NJ: Erlbaum.

Quinn, N. (2005). Universals of child rearing. Anthropological Theory, 5, 477-516.

Reyes-Garcia, V., Broesch, J., \& TAPS Bolivian Study Team (2013). The transmission of ethnobotanical knowledge and skills among Tsimanè in the Bolivian Amazon. In R. Ellen, S. J. Lycett, \& S. E. Johns (Eds.), Understanding cultural transmission in anthropology (pp. 181-212). New York, NY: Berghahn.

Rheingold, H. (1982). Little children's participation in the work of adults, a nascent prosocial behavior. Child Development, 53, 114-125.
Rival, L. M. (2000). Formal schooling and the production of modern citizens in the Ecuadorian Amazon. In B. A. U. Levinson (Ed.), Schooling the symbolic animal: Social and cultural dimensions of education (pp. 108-122). Lanham, MD: Rowman \& Littlefield.

Rogoff, B., Correa-Chávez, M., \& Navichoc-Cotuc, M. (2005). A cultural/historical view of schooling in human development. In D. Pillemer \& S. H. White (Eds.), Developmental psychology and social change. New York, NY: Cambridge University Press.

Shostak, M. (1981). Nisa: the life and words of a !Kung woman. New York, NY: Vintage Books.

Shutt, E. J., Miller, M. J., Schreck, C. J., \& Brown, N. K. (2004). Reconsidering the leading myths of strangerchild abduction. Criminal Justice Studies, 17, 127-134.

Spittler, G. (1998). Hirtenarbeit. Cologne, Germany: Rüdiger Köppe.

Stieglitz, J., Gurven, M., Kaplan, H., \& Hooper, P. L. (2013). Household task delegation among high-fertility forager-horticulturalists of Lowland Bolivia. Current Anthropology, 54, 1-10.

Takada, A. (2012). Preverbal infant-caregiver interaction. In A. Duranti, E. Ochs, \& B. B. Schieffelin (Eds.), The handbook of language socialization (pp. 56-80). West Sussex, UK: Wiley Blackwell.

Tayanin, D., \& Lindell, K. (1991). Hunting and fishing in a Kammu village. Studies in Asian Topics, 14. Copenhagen, Denmark: Curzon Press.

Thornton, A., \& Raihani, N. J. (2008). The evolution of teaching. Animal Behaviour, 75, 1823-1836.

Tomasello, M. (1999). The cultural origins of human cognition. Cambridge, MA: Harvard University Press.

Toren, C. (2001). The child mind. In H. Whitehouse (Ed.), The debated mind: Evolutionary psychology versus ethnography (pp. 155-179). Oxford, UK: Berg.

Vermonden, D. (2009). Reproduction and development of expertise within communities of practice: A case study of fishing activities in South Buton. In S. Heckler (Ed.), Landscape, process, and power: Re-evaluating traditional environmental knowledge (pp. 205-229). Oxford, UK: Berghahn Books.

Warneken, F., \& Tomasello, M. (2006). Altruistic helping in human infants and young chimpanzees. Science, 311, 1301-1303.

Warneken, F., \& Tomasello, M. (2009). The roots of human altruism. British Journal of Psychology, 100, 455471.

Watson-Gegeo, K. A., \& Gegeo, D. W. (1989). The role of sibling interaction in child socialization. In P. G. Zukow (Ed.), Sibling interaction across cultures (pp. 54-76). New York, NY: Springer-Verlag.

Watson-Jones, R. E., Legare, C. H., Whitehouse, H., \& Glegg, J. M. (2014). Task-specific effects of ostracism on imitative fidelity in early childhood. Evolution and Human Behavior, 35, 204-210.

Weisner, T. S., \& Gallimore, R. (1977). My brother's keeper: Child and sibling caretaking. Current Anthropology, 18, 169-190. 
Wenger, M. (1989). Work, play and social relationships among children in a Giriama community. In D. Belle (Ed.), Children's social networks and social supports (pp. 91-115). New York, NY: Wiley.

White, R. W. (1959). Motivation reconsidered: The concept of competence. Psychological Review, 66, 297-333.

Whiten, A., McGuigan, N., Marshall-Pescini, S., \& Hopper, L. M. (2009). Emulation, imitation, over-imitation and the scope of culture for child and chimpanzee. Philosophical Transactions of the Royal Society B: Biological Sciences, 364, 2417-2428.
Wilbert, J. (1976). To become a maker of canoes: An essay in Warao enculturation. In J. Wilbert (Ed.), Enculturation in Latin America (pp. 303-358). Los Angeles, CA: UCLA Latin American Center Publications.

Williams, T. R. (1969). A Borneo childhood: Enculturation in Dusun society. New York, NY: Holt, Reinhart, and Winston.

Zelazo, P. R., Zelazo, N. A., \& Kolb, S. (1972). "Walking" in the newborn. Science, 176, 314-315.

Zelizer, V. A. (1985). Pricing the priceless child: The changing social value of children. New York, NY: Basic Books. 